\title{
Italy: A Question of Interest Rates and Trust
}

Contrary to the image generally portrayed to Northern European countries, Italy is not a fiscally profligate country. Indeed, Italy has a record of primary fiscal surpluses (balances that exclude interest rate payments) since 1992; only Germany can make a similar claim. Regrettably, this uninterrupted series of budget surpluses was accompanied by a loss of external competitiveness due to the approaching and later adoption of the euro since 1995. These two factors combined to form the deep root of the long-term sluggishness of the Italian economy, particularly of its labour productivity stagnation. The supply side factors do matter, of course, given the increased global competitive environment, but the demand side factors are the main drivers of this development.

High Italian public debt dates back to the 1980s, to the period of Italian participation in the European Monetary System (EMS). This membership was justified - as it was also later in the European Monetary Union (EMU) - as a way to import foreign discipline. The consequent loss of foreign competitiveness was a determinant of the increasing public debt: directly, by negatively affecting aggregate demand and fiscal revenues; and indirectly, through the need to attract foreign financing through higher interest rates. And of course, the refusal of the governments of that period to adopt austerity policies contributed to the increase in debt. As Joseph Stiglitz has pointed out, however, countries with persistent or expanding external deficits are often forced to run fiscal deficits to sustain domestic demand: "Without fiscal deficit, they will have high unemployment".

Be this as it may, high interest rate payments in the 1980 s were the main cause of the increase in public debt. This was also the case in the early 1990s after the full liberalisation of capital flows and the necessity of stabilising the Italian lira after the exit from the EMS in 1992. During the pre-crisis euro years, Italy benefited from lower interest rates that, combined with austerity policies, led to a substantial fall of the public debt/GDP ratio from $125 \%$ in the mid 1990 s to $100 \%$ in 2007. The price, however, was the stagnation of the Italian economy. In the following years, high interest rates caused by the delayed and insufficient intervention of the ECB to support Italian sovereign bonds as well as the negative impact of the austerity measures on GDP and fiscal revenues caused this ratio to rise to its current level of $130 \%$.

In synthesis, Italian public debt has had mainly to do with interest rate payments and conversely very little to do with fiscal profligacy. David Folkerts-Landau, chief economist of Deutsche Bank, has recently acknowledged "contrary to widespread prejudice, Italy has been a frugal country". ${ }^{2}$

During his recent attacks on the Italian government, Pierre Moscovici - the European Commissioner for Economic and Financial Affairs, Taxation and Customs - stated that since Italy is paying about 65 billion euros for interest payments on its public debt, at the expense of its citizens, the only way to reduce this cost is by cutting the debt. The experience suggests that policies that aim to abate the debt are a useless Sisyphus fatigue since they depress the GDP. It is also known that interest rates are mainly determined by the central bank, unless markets are left to operate freely. It is unfortunate that most of the German élite share Commerzbank chief economist Jörg Krämer's view that markets should be allowed to bring Italy to heel. The European Commission also lamentably endorses this argument.

1 J.E. Stiglitz: Freefall: America, Free Markets, and the Sinking of the World Economy, London 2010, W.W. Norton \& Company, p. 235.

2 S. Cesaratto, A. Iero: It's the interest rate, stupid!, Brave New Europe, 17 November 2018, available at https://braveneweurope.com/sergio-cesaratto-and-antonio-iero-its-the-interest-rate-stupid. 
There is, however, another solution for Italy and Europe: operate to allow interest rates on Italian public debt to fall to, e.g., the French level (that is, nearly the German level). With sufficiently low interest rates, a stabilisation and even a slow, progressive reduction of the Italian public debt is consistent with a moderate fiscal expansion aimed at sustaining the Italian domestic demand. Folkerts-Landau has recently endorsed this approach as it may be undertaken without preoccupations of moral hazard on the part of the Italian authorities.

The next question is how to achieve the grand bargain between Italy and Europe comprised of low interest rates and support for Italian growth in exchange for a firm commitment to fiscal consolidation. In my view, it would be unacceptable for Italy to implement this in the terms proposed by Folkerts-Landau, i.e. through an application of the ECB's Outright Monetary Transactions (OMT) accompanied by a memorandum of understanding and an intervention of the European Stability Mechanism (ESM). One may recall that the OMT was the 'big bazooka' that Mario Draghi displayed in summer 2012 to calm down the financial markets; its utilisation was subordinated to a memorandum and to the ESM intervention. In Folkerts-Landau's view the memorandum should contemplate some structural reforms. But the necessity of structural reforms is just an unfortunate mantra. Italy certainly needs to change its habits and institutions, but this requires funds and investment. A memorandum should of course be stipulated, but as a symbol of a reinvigorated trust between Italy and Europe. Moreover, an ESM loan would not be politically acceptable. It would suffice if the ECB accompanies the OMT (or threatens to do so) by putting its money where its mouth is, e.g. the resumption of the Security Market Program, in which the Bank bought government bonds of selected euro area countries from 2010 to 2012. Actually, it should be the ECB's duty to restore a uniform transmission of monetary policy to the whole euro area (which implies convergent interest rates on government bonds).

If Europe conceded that the solution to the Italian debt overhang was not outright austerity, as Folkerts-Landau claims, would the current Italian government be ready for the grand bargain? In the document sent in September the Italian Minister of European Affairs, the senior monetary economist Paolo Savona specifically mentioned the necessity of selective ECB support. The moderate Minister of Economy and Finance, economist Giovanni Tria, has correctly rebuffed the European Commission's request for a restrictive budget policy as it would condemn Italy to a new recession, and has stressed the fact that growth policies imply an international fiscal and monetary coordination and cannot be confined to the national level (through 'structural reforms') as in common European philosophy.

Admittedly, the present government coalition has heavily indulged in demagogic electoral promises, which it now feels obliged to partially fulfil such as basic income and early retirement. If hastily implemented, measures like the former will be subject to diffuse free riding with little connection to vocational training and local job creation. A robust extension of the existing poverty measures would have been more advisable. The impact of the fiscal manoeuvres on aggregate demand is doubtful. Given the European slowdown and the less than encouraging expectations, the government's projected growth rate appears rather optimistic. More sensible would have been an investment plan in both rapidly implemented civil works to reconfigure the existing public infrastructure and create jobs, and to build new ones in the longer term. This would deliver jobs in the south, rather than subsidies. Italy would thus have the opportunity to present itself with respectable credentials in Brussels: the failure of the austerity policies, a record of fiscal moderation, solid foreign accounts, a fiscal budget focused on investment that could not be blamed of adventurism. There would be no reason why Italy should be denied the same interest rate level as France, thereby reconciling moderate growth and consolidation of the debt. Europe should be aware that this lack of mutual understanding bears a high risk of a financial crash in Italy. In this case, acceptance of the Troika in this country would be inconceivable. The Italian government, but more prominently the European governments and élites, will

Sergio Cesaratto, Università die Siena, Italy. be responsible for the eventual dramatic conclusion. 